\title{
Preface to the special issue on biohydrology dedicated to the memory of Dr. Louis W. Dekker
}

\author{
Paul D. Hallett ${ }^{1 *}$, Tammo S. Steenhuis ${ }^{2,3}$, Coen Ritsema ${ }^{4}$, Lubomír Lichner ${ }^{5}$ \\ ${ }^{1}$ School of Biological Sciences, University of Aberdeen, Aberdeen, AB24 3UU, UK. \\ ${ }^{2}$ Department of Biological and Environmental Engineering, 206 Riley Robb Hall, Cornell University, Ithaca, NY, 14853 USA. \\ ${ }^{3}$ Faculty of Civil and Water Resources Engineering, Bahir Dar University, Bahir Dar, Ethiopia. \\ ${ }^{4}$ Soil Physics and Land Management Group, Wageningen University, the Netherlands. \\ ${ }^{5}$ Institute of Hydrology, Slovak Academy of Sciences, Dúbravská cesta 9, 84104 Bratislava, Slovak Republic. \\ * Corresponding author. E-mail: paul.hallett@abdn.ac.uk
}

Over a scientific career spanning an amazing 63 years, Dr. Louis W. Dekker advanced our understanding of soil and hydrological processes greatly. He sadly passed away in November 2019 at the age of 80 , while still actively involved in research. He left behind a scientific legacy that will continue to influence research in the years to come. This special issue on Biohydrology is dedicated to the memory of Dr. Louis Dekker. His impact is reflected not only in the citations to his work by the 14 papers in this special issue that covers topics ranging from water use by plants to soil water repellency, but more importantly by the many scientists that had the privilege to work with him. They are carrying forward his excitement for soil science and its many unique aspects.

It is fitting to pay tribute to Dr. Louis Dekker in this Biohydrology Special Issue, as he was a founder of the Biohydrology conferences that emerged from a meeting at the European Geosciences Union in 2005. Due to his international prominence, he was selected as chairman of the 1st Biohydrology conference in Prague in 2006 and was guest-editor of the 1st Special issue on biohydrology published in Biologia in 2006. A legacy of these conferences was a network of multidisciplinary researchers who last met at the $5^{\text {th }}$ Biohydrology conference in Valencia, Spain in 2019. Earlier, in 1998, along with his very close colleague Prof. Coen Ritsema, he hosted a workshop at his home institution (DLO Winand Staring Centre for Integrated Land, Soil and Water Research in Wageningen) that was the beginning of the soil water repellency research community. This workshop produced a special issue of the Journal of Hydrology with an impressive 32 articles that have so far been cited about 3700 times (Ritsema and Dekker, 2000).

Dr. Louis Dekker started his career in 1956 as a soil surveyor for Stiboka. He became fascinated by the patterns of soils in the landscape while making the soil maps (Dekker and Deweerd, 1973). After all Dutch soils were surveyed in the 1970 s, he immersed himself in finding the origins of the patterns he noticed earlier while discovering new ones at the same time by taking thousands of field samples not only in the Netherlands but in other countries that he happened to visit. Based on this fieldwork, he was the first to claim the phrase that preferential flow was the rule rather than the exception. He also discovered the widespread occurrence of water repellency in temperate climates and questioned the common assumption that soil water repellency was a rare property limited to a few soils in extreme environments (Dekker and Ritsema, 1996; Dekker et al., 2001). Based on his seminal research work, he was awarded a doctorate on the same day as his colleague and friend Coen Risema in 1998. He is one of the very few people that earned this honour without a formal university education. His research was just that outstanding.

One of his major contributions was identifying and quantifying the temporal nature of soil water repellency, which he found was often, but not always linked to fluctuations in water content and temperature (Dekker et al., 1998). He co-authored one of the early seminal articles describing the physics of water repellent soil (Bauters et al., 2000) and provided some of the earliest evidence linking water repellency to preferential flow path development (Dekker and Ritsema, 1996; Ritsema and Dekker, 1996). Dr. Louis Dekker's pioneering soil water repellency research has led to a surge in interest starting in the 1990s (Dekker et al., 2005b). This special issue that reports on the biohydrology workshop is built on the achievements of Dr. Louis Dekker.

Dr. Louis Dekker developed robust techniques to characterise soil water repellency in the field (Dekker et al., 2009) and applied them to a range of challenges such as water repellency induced by forest fires (Stoof et al., 2011) and vegetation (Oostindie et al., 2017). He sought approaches to combat water repellency that provided a large contribution to the development of surfactants used in agriculture and the turfgrass industry (Dekker et al., 2005a, 2019). The review article by Fidanza et al. (2020) reviews water repellency development in intensively managed amenity turf, including a focus on the use of surfactants. The 20 citations to Dr Louis Dekker's work in this article reflect his impact and high esteem. Fidanza et al. (2020) found that both scientific and trade literature on water repellency in turf has grown dramatically in recent years, accompanied by the development of about 200 surfactant formulations in the USA alone. They highlighted research on dune systems by Dekker et al. (2001) as a key study that has guided turfgrass scientists and practitioners.

Desert systems share similar properties to coastal dunes, including continual burial of surfaces by newly deposited sand. Jia et al. (2020) found that sand burial caused a marked decrease in water repellency, but unless burial depth was greater than $0.5 \mathrm{~mm}$, water repellency rapidly re-emerged and reached levels worse than before burial. Soil water repellency can also be a major challenge in forested land, as investigated by Piyaruwan et al. (2020). They showed that nonindigenous eucalyptus and pine trees exacerbated soil water repellency, which was reflected in decreased groundwater levels that the authors argued arose from depleted recharge through the soil from precipitation. This interdisciplinary study modelled groundwater levels over the past 40 years from remote sensing data and assessed the social impact by questionnaires to the surrounding 
communities on well water availability. Eucalyptus and pine trees in this region should be replaced by species that have less impact on soil water repellency and groundwater recharge.

Nonindigenous tree species can also be difficult to manage during periods of drought when they may be susceptible to water deficit and high temperatures. Leštianska et al. (2020) assessed drought and temperature impacts from measurements of stem water deficit and maximum daily shrinkage for a number of tree species in 2018 when it was extremely hot and dry, and in 2017 when temperature and precipitation were close to average. They found that Larix decidua and Picea abies, which are not native to central Slovakia where the study was conducted, were affected more by heat and drought than Abies alba and Pinus sylvestris. This study is highly significant in identifying economically important tree species that can cope with erratic weather that is occurring more frequently. The spatial impact of groundwater availability on forest decline was examined with geostatistics and multi-criteria analysis by Jokanović et al. (2020). This approach allowed for areas in danger of forest decline to be identified so that they could be protected.

Wild olive trees are highly adapted to extremely dry soil conditions, which Corona and Montaldo (2020) demonstrated was due to their ability to access water through fractures in the underlying bedrock. They argued that ecohydrology often ignores this source of water that provided $97 \%$ of evapotranspiration in a dry summer. Although current precipitation in Sardinia, where the study was conducted, is sufficient to recharge deep water each year, future climate predictions suggest that wild olive trees will be at risk.

In commercial olive tree and vegetable production, intensive tillage often occurs that can mineralise carbon and structurally destabilise soils. Bogunovic et al. (2020) found that adding grass cover and removing tillage in olive tree management resulted in marked improvements to nutrient retention, soil loss, structural stability, and run-off. A new technology that could alleviate the use of tillage in weed control and also help to conserve water in soils is the application of hydromulches. Verdú et al. (2020) observed that under very dry conditions that almost completely dried soils, hydromulches resulted in only a $67 \%$ loss in water. Moreover, the mechanical strength of the hydromulch was sufficient to suppress the emergence of weed seedlings.

As freshwater resources are depleted and under increasing pressure for a range of uses, treated wastewater is increasingly used for irrigation. This presents a potential risk of antibiotics contaminating the environment, which could have negative impacts on soil microbial communities. In a laboratory study, Fér et al. (2020) measured that increasing the concentration of the antibiotic sulfamethoxazole resulted in an exponential increase in carbon dioxide efflux. In the field, this could result in increased greenhouse gas emissions and harm the capacity of the soil microbial community to perform functions such as nutrient cycling. Another soil management approach that may conserve water and have added benefits to carbon sequestration and greenhouse gas emissions is tillage. There is a paucity of field based data on how tillage influences emissions, so the study by Horák et al. (2020) provided valuable new insight. They found that tillage caused negligible difference in $\mathrm{CO}_{2}$ and $\mathrm{N}_{2} \mathrm{O}$ emissions over the growing season, with the best predictors of emissions being temperature in the early season and water-filled pore space later in the growing season.

Other papers in this special issue provide new evidence that challenges common perceptions. It is commonly thought that dew provides a major water source for desert lichens. However, using climate data and published data on the photosynthetic activity of lichen, Kidron and Kronenfeld (2020) predicted that most of the water used by lichens in the Tabernas desert comes from rain. Lichen is a rock dwelling organism that tends to inhabit north facing slopes in the Negev Highlands where this research was conducted, whereas cyanobacteria inhabit south facing slopes. Kidron and Starinsky (2020) found that different mineral weathering between these organisms drove aspect dependent ion enrichment of run-off water. Whilst some ions $\left(\mathrm{Ca}^{2+}\right.$ and $\left.\mathrm{HCO}_{3}{ }^{-}\right)$could be explained by the parent material, $\mathrm{K}^{+}$ was associated with cyanobacteria and $\mathrm{Mg}^{2+}$ was associated with lichen.

Addisie et al. (2020) provide new data and modelling of hillslope hydrology from the Ethiopian highlands that was the first to incorporate subsurface flow through a perched water table. Unlike temperate climates where soils tend to be moist at crop sowing and then dry out progressively, in tropical regions soils tend to be dry at the beginning of cropping and then get progressively wetter into the rainy season. By combining subsurface flow through the perched water table and overland flow, Addisie et al. (2020) quantified the dominant sources of stream water. Model predictions of water table height and discharge from the watershed fit fairly well to experimental data. Improving predictions further requires far more field investigations using more sophisticated measurement approaches across the complex Ethiopian highlands.

A modified laboratory measurement approach for assessing soil water infiltration and repellency was developed by Sepehrnia et al. (2020). They adapted a microinfiltrometer developed by Leeds-Harrison et al. (1994) to enhance the tension range and conductance of the tip in contact with soil, and to decrease measurement error from tube deformation and evaporation. This new device allowed for measurements at tensions up to $-40 \mathrm{~cm}$ and for readings over several days, so that water repellency breakdown and a broad range of conducting pore sizes could be explored. Advancing approaches to measure soil water repellency in the laboratory and field were major outcomes of Dr. Louis Dekker's research too (Dekker et al., 2009), as evident from the 8 citations to his research by Sepehrnia et al. (2020).

The diverse nature of papers in this special issue, all dealing with various hydrological processes and challenges, reflect the breadth of Dr. Louis Dekker's research. He actively promoted his discipline by editing special issues, so we hope this special issue goes some way to continue this tradition. Soil and hydrological sciences lost a great investigator, but the citations to so many of Dr. Louis Dekker's papers in this special issue are evidence that his memory and impact on research will continue for many years to come.

\section{REFERENCES}

Addisie, M.B., Ayele, G.K., Hailu, N., Langendoen, E.J., Tilahun, S.A., Schmitter, P., Parlange, J.-Y., Steenhuis, T.S., 2020. Connecting hillslope and runoff generation processes in the Ethiopian Highlands: The Ene-Chilala watershed. J. Hydrol. Hydromech., 68, 4, 313-327.

Bauters, T.W.J., Steenhuis, T.S., DiCarlo, D.A., Nieber, J.L., Dekker, L.W., Ritsema, C.J., Parlange, J.-Y., Haverkamp, R., 2000. Physics of water repellent soils. J. Hydrol., 231232, 233-243.

Bogunovic, I., Telak, L.J., Pereira, P., Filipovic, V., Filipovic, L., Percin, A., Durdevic, B., Birkás, M., Dekemati, I., Rodrigo-Comino, J., 2020. Land management impacts on soil properties and initial soil erosion processes in olives and vegetable crops. J. Hydrol. Hydromech., 68, 4, 328-337. 
Corona, R., Montaldo, N., 2020. On the transpiration of wild olives under water-limited conditions in a heterogenous ecosystem with shallow soil over fractured rock. J. Hydrol. Hydromech., 68, 4, 338-350.

Dekker, L.W., Deweerd, M.D., 1973. Value of soil survey for archeology. Geoderma, 10, 169-178.

Dekker, L.W., Ritsema, C.J., 1996. Uneven moisture patterns in water repellent soils. Geoderma, 70, 87-99.

Dekker, L.W., Ritsema, C.J., Oostindie, K., Boersma, O.H., 1998. Effect of drying temperature on the severity of soil water repellency. Soil Sci., 163, 780-796.

Dekker, L.W., Doerr, S.H., Oostindie, K., Ziogas, A.K., Ritsema, C.J., 2001. Water repellency and critical soil water content in a dune sand. Soil Sci. Soc. Am. J., 65, 1667-1674.

Dekker, L.W., Oostindie, K., Kostka, S.J., Ritsema, C.J., 2005a. Effects of surfactant treatments on the wettability of a water repellent grass-covered dune sand. Aust. J. Soil Res., 43, 383-395.

Dekker, L.W., Oostindie, K., Ritsema, C.J., 2005b. Exponential increase of publications related to soil water repellency. Aust. J. Soil Res., 43, 403-441.

Dekker, L.W., Ritsema, C.J., Oostindie, K., Moore, D., Wesseling, J.G., 2009. Methods for determining soil water repellency on field-moist samples. Water Resour. Res., 45, 4, W00D33. DOI:10.1029/2008WR007070.

Dekker, L.W., Ritsema, C.J., Oostindie, K., Wesseling, J.G., Geissen, V., 2019. Effects of a soil surfactant on grass performance and soil wetting of a fairway prone to water repellency. Geoderma, 338, 481-492.

Fér, M., Kodešová, R., Kalkušová, B., Klement, A., Nikodem, A., 2020. An empirical model for describing the influence of water content and concentration of sulfamethoxazole (antibiotic) in soil on the total net $\mathrm{CO}_{2}$ efflux. J. Hydrol. Hydromech., 68, 4, 351-358.

Fidanza, M., Kostka, S., Bigelow, C., 2020. Communication of soil water repellency causes, problems, and solutions of intensively managed amenity turf from 2000 to 2020 . J. Hydrol. Hydromech., 68, 4, 306-312.

Horák, J., Igaz, D., Aydin, E., Šimanský, V., Buchkina, N., Balashov, E., 2020. Changes in direct $\mathrm{CO}_{2}$ and $\mathrm{N}_{2} \mathrm{O}$ emissions from a loam Haplic Luvisol under conventional moldboard and reduced tillage during growing season and post-harvest period of red clover. J. Hydrol. Hydromech., $68,3,271-278$.

Jia, R.L., Gao, Y.H., Liu, L.C., Yang, H.T., Zhao, Y., 2020. Effect of sand burial on the subcritical water repellency of a dominant moss crust in a revegetated area of the Tengger
Desert, Northern China. J. Hydrol. Hydromech., 68, 3, 279-284.

Jokanović, V.N., Vulević, T., Lazarević, K., 2020. Risk assessment of forest decline by application of geostatistics and multi-criteria analysis. J. Hydrol. Hydromech., 68, 3, 285-292.

Kidron, G.J., Kronenfeld, R., 2020. Atmospheric humidity is unlikely to serve as an important water source for crustose soil lichens in the Tabernas Desert. J. Hydrol. Hydromech., $68,4,359-367$.

Kidron, G.J., Starinsky, A., 2020. Lithobiont-dependent ionic composition in runoff water. J. Hydrol. Hydromech., 68, 3, 293-301.

Leeds-Harrison, P.B., Youngs, E.G., Uddin, B., 1994. A device for determining the sorptivity of soil aggregates. Eur. J. Soil Sci., 45, 269-272.

Leštianska, A., Fleischer, P. Jr., Fleischer, P., Merganičová, K., Střelcová, K., 2020. Interspecific variation in growth and tree water status of conifers under water-limited conditions. J. Hydrol. Hydromech., 68, 4, 368-381.

Oostindie, K., Dekker, L.W., Wesseling, J.G., Geissen, V., Ritsema, C.J., 2017. Impacts of grass removal on wetting and actual water repellency in a sandy soil. J. Hydrol. Hydromech., 65, 88-98.

Piyaruwan, H.I.G.S., Jayasinghe, P.K.S.C., Leelamanie, D.A.L., 2020. Water repellency in eucalyptus and pine plantation forest soils and its relation to groundwater levels estimated with multi-temporal modeling. J. Hydrol. Hydromech., 68, 4, 382-391.

Ritsema, C.J., Dekker, L.W., 1996. Water repellency and its role in forming preferred flow paths in soils. Aust. J. Soil Res., 34, 475-487.

Ritsema, C.J., Dekker, L.W., 2000. Special issue: Water repellency in soils - Preface. J. Hydrol., 231, 1-3.

Sepehrnia, N., Woche, S.K., Goebel, M.-O., Bachmann, J., 2020. Development of a universal microinfiltrometer to estimate extent and persistence of soil water repellency as a function of capillary pressure and interface chemical composition. J. Hydrol. Hydromech., 68, 4, 392-403.

Stoof, C.R., Moore, D., Ritsema, C.J., Dekker, L.W., 2011. Natural and fire-induced soil water repellency in a portuguese shrubland. Soil Sci. Soc. Am. J., 75, 22832295.

Verdú, A.M.C., Mas, M.T., Josa, R., Ginovart, M., 2020. The effect of a prototype hydromulch on soil water evaporation under controlled laboratory conditions. J. Hydrol. Hydromech., 68, 4, 404-410. 